\title{
Electrochemical Separation of Barium into Liquid Bismuth by Controlling Deposition Potentials
}

Hojong $\operatorname{Kim}^{1}{ }^{*}$, Nathan $\operatorname{Smith}^{1}$, Kuldeep $\operatorname{Kumar}^{1}$, Timothy Lichtenstein ${ }^{1}$

${ }^{1}$ Materials Science and Engineering, The Pennsylvania State University, 406 Steidle Building, University Park, PA 16802, United States of America

Author E-mail addresses:

huk29@psu.edu,nds174@psu.edu, kxk1023@psu.edu, tv15297@psu.edu,

Corresponding Author:

*Email: huk29@psu.edu. Tel: 814-865-3117. Fax: 814-865-2917

KEYWORDS: Electrochemical Separation, Liquid Electrode, Liquid Alloys, Molten Salt

Electrolyte, Alkaline-earth separation, Liquid Bismuth, Barium 


\begin{abstract}
Electrochemical separation of barium from multi-component molten salt electrolyte $\left(\mathrm{BaCl}_{2}-\mathrm{LiCl}\right.$ $\mathrm{CaCl}_{2}-\mathrm{NaCl}$ ) at $500-700{ }^{\circ} \mathrm{C}$ is demonstrated using liquid bismuth electrode which possesses strong chemical interactions with barium. While the standard emf analysis suggests $\mathrm{Na}$ to be the first species to deposit in this electrolyte followed by $\mathrm{Ca}, \mathrm{Li}$, and finally $\mathrm{Ba}$, barium was found to be the first species to be reduced into the bismuth electrode followed by $\mathrm{Ca}$. The exceptional deposition behavior of barium was ascribed to the activity of the constituent alkali/alkaline-earth metals in the bismuth metal. The activity of barium in bismuth was extremely low (as low as $10^{-15}$ ), shifting the redox potential of barium to the most positive potentials and enabling the separation of barium into liquid bismuth. By exploiting the differential interactions of constituent ions with the liquid bismuth, it was possible to separate conventionally non-separable barium species from the electrolyte solution. In addition, high coulombic efficiencies of the liquid bismuth electrode (>99\%) suggest that electrode processes are chemically reversible for codeposition of barium and calcium. The analyses of electrode potentials at various current densities and electrochemical impedance spectra indicate charge transfer as the most significant overpotential mechanism during electrolysis.
\end{abstract}




\section{INTRODUCTION}

Alkali/alkaline-earth metals are highly reactive, characterized by low standard electrode potentials, and their halides are often employed as constituents of a supporting electrolyte (as non-electroactive ions). According to the standard electrode potentials of alkali/alkaline-earth elements in the chloride system at $600{ }^{\circ} \mathrm{C}$ (Figure 1)[1], one would expect barium metal to deposit last from a solution of alkali/alkaline-earth metal chlorides as it has the highest stability in the electrolyte, indicated by its redox potential $\left(E_{\mathrm{Ba}^{2+} / \mathrm{Ba}^{2}}^{0}=-3.74 \mathrm{~V}\right.$ vs. $\left.\mathrm{Cl}^{-} / \mathrm{Cl}_{2}(\mathrm{~g})\right)$. In other words, barium is one of the most challenging species to separate from the electrolyte solution electrochemically.

While the reduction of the most stable species in the electrolyte (e.g., $\mathrm{Ba}^{2+}$ in the chloride system) is not feasible based upon the analysis of standard electrode potentials, we will demonstrate the feasibility of separating these stable species using liquid metal electrodes that possess preferential, strong chemical interactions with these elements. More specifically, we will present unusual deposition behavior of barium into liquid bismuth electrodes $\left(T_{\mathrm{m}, \mathrm{Bi}}=271{ }^{\circ} \mathrm{C}\right)$ from the multi-component $\mathrm{BaCl}_{2}-\mathrm{LiCl}-\mathrm{CaCl}_{2}-\mathrm{NaCl}$ (16-29-35-20 mol\%) electrolyte, based upon the thermodynamic analysis of electrode reactions at $500-700{ }^{\circ} \mathrm{C}$. This finding is believed to occur due to the strong interaction between liquid bismuth and barium metals, switching the sequence of deposition potentials of the constituent ions.

\section{[Figure 1]}

This study also suggests that the use of strongly interacting liquid metals enables us to separate out the most stable ionic species from electrolyte solutions, providing a direct methodology to purify electrolyte solutions contaminated with stable alkali/alkaline-earth elements in electrochemical refining or separation processes. For example, in electrochemical 
separation of uranium from used nuclear fuels in molten salt electrolytes (e.g., LiCl-KCl), a periodic replacement of electrolyte solution is required due to the accumulation of the alkali/alkaline-earth elements (e.g., $\mathrm{Ba}^{2+}, \mathrm{Cs}^{+}$, or $\mathrm{Sr}^{2+}$ ) that changes the physical and chemical properties of the electrolyte thereby generating an excessive volume of nuclear waste.[2, 3] The liquid metal electrodes can separate these conventionally non-separable alkali/alkaline-earth elements from the electrolyte solution, enabling direct purification, recycling of electrolytes, and reduction in the volume of nuclear waste.

Liquid metals possess unique electrochemical deposition properties due to their capacity to form an alloy phase with reduced species. These liquid metal electrodes have been widely employed in electrochemical technologies for separating target elements through selective deposition and for electrochemical energy storage devices, utilizing their inherently high electronic conductivity, high liquid-state solubility, and fast mass transport kinetics.[2, 4] Because the composition of liquid electrodes changes continuously during the deposition process due to alloying reactions, the thermodynamic properties of liquid alloys such as activity should be considered in investigating the interfacial electrode processes. Obviously, the equilibrium potential of liquid alloys will deviate from the standard potentials which are defined at unit activity values for both reactants and products, depending upon the thermodynamic activity values of redox species in liquid alloys.

In liquid bismuth, the thermodynamic activity values of alkali/alkaline earths $(\mathrm{A}=\mathrm{Li}, \mathrm{Na}$, $\mathrm{Ca}$, and $\mathrm{Ba}) a_{\mathrm{A}(\mathrm{in} \mathrm{Bi})}$ were determined primarily using electrochemical cells that measure the electromotive force (emf) between the pure metal (A) and the alloys (A-Bi), as summarized in Table 1 at a constant mole fraction of $x_{\mathrm{A}(\mathrm{in} \mathrm{Bi})}=0.05$ at $600^{\circ} \mathrm{C}$.[5-9] These thermodynamic properties were obtained using a $\mathrm{LiCl}-\mathrm{LiF}$ electrolyte for $\mathrm{Li}-\mathrm{Bi}$, sodium- $\beta^{\prime \prime}$ alumina for $\mathrm{Na}-\mathrm{Bi}$, 
$\mathrm{CaF}_{2}$ for $\mathrm{Ca}-\mathrm{Bi}$, and $\mathrm{BaF}_{2}$ for $\mathrm{Ba}-\mathrm{Bi}$ systems. The activity values of these elements in liquid $\mathrm{Bi}$ are extremely low and span over ten orders of magnitude $\left(10^{-5}<a_{\mathrm{A}(\mathrm{in} \mathrm{Bi})}<10^{-15}\right)$, implying (i) strong chemical interactions between alkali/alkaline-earth metals with bismuth metal, (ii) a large thermodynamic driving force for alloying (reduction) reactions, and (iii) a substantial shift in the equilibrium potentials of alkali/alkaline-earths from their standard potentials. In particular, a wide range of activity values among alkali/alkaline-earth elements can lead to a unique series of equilibrium potentials, distinct from the series of standard electrode potentials.

\section{[Table 1]}

To understand the deposition sequence of alkali/alkaline-earths into liquid bismuth, it is important to recognize that the equilibrium potential of the bismuth electrode relies on the activity values of each alkali/alkaline-earth metals which will also change as a function of composition. A generic half-cell reaction at the liquid bismuth electrode can be written as:

$$
\mathrm{A}^{n+}+n \mathrm{e}^{-}=\mathrm{A}(\text { in } \mathrm{Bi})
$$

, where $\mathrm{A}$ represents alkali/alkaline-earth elements $(\mathrm{A}=\mathrm{Ba}, \mathrm{Li}, \mathrm{Ca}$, and $\mathrm{Na})$ and $n$ is the number of electrons exchanged in the reaction ( $n=1$ for alkali and $n=2$ for alkaline-earth metals). Then, the equilibrium potential of each element $E_{\text {eq }}$ is defined as follows according to the Nernst equation:

$$
E_{\mathrm{eq}}=E_{\mathrm{A}^{\mathrm{n}+\mathrm{A}}}^{0}-\frac{R T}{n F} \ln \left(\frac{a_{\mathrm{A}(\mathrm{in} \mathrm{Bi})}}{a_{\mathrm{A}^{\mathrm{n}+}}}\right)
$$

, where $E_{\mathrm{A}^{n+} / \mathrm{A}}^{0}$ is the standard electrode potential of $\mathrm{A}^{n+} / \mathrm{A}$ couple, $R$ is the gas constant, $T$ is the temperature, $F$ is the Faraday constant, and $a$ are the activity values of the reactant and product.

Using the above Nernst equation, the equilibrium potentials of each binary A-Bi alloy $E_{\text {eq }}$ at $600{ }^{\circ} \mathrm{C}$ were estimated at constant mole fraction $x_{\mathrm{A}(\mathrm{in} \mathrm{Bi})}=0.05$ using the activity values of $a_{\mathrm{A}(\mathrm{in}}$ 
Bi) in the pure electrolyte $\left(a_{\mathrm{A}^{n+}}=1\right)$, as summarized in Table 1 and graphically presented in Figure 2. Comparing the series of electrode potentials in standard states and in the liquid bismuth electrode, the deposition sequence of elements into the bismuth electrode is as follows: $\mathrm{Ba} \rightarrow \mathrm{Ca}$ $\rightarrow \mathrm{Na} / \mathrm{Li}$, in contrast to the standard sequence of $\mathrm{Na} \rightarrow \mathrm{Ca} \rightarrow \mathrm{Li} \rightarrow \mathrm{Ba}$ due to a substantial difference in thermodynamic activity values among alkali/alkaline-earths in liquid bismuth. This analysis suggests that the extremely low activity value of barium in bismuth $\left(3.7 \times 10^{-15}\right)$ leads to the most significant potential change $(1.25 \mathrm{~V})$ and enables a preferential deposition of barium into a liquid bismuth electrode, in good agreement with our experimental observation where preferential deposition of barium occurs along with co-deposition of calcium.

\section{[Figure 2]}

When electrolysis is performed in $\mathrm{BaCl}_{2}-\mathrm{LiCl}-\mathrm{CaCl}_{2}-\mathrm{NaCl}$ electrolyte using noninteracting inert electrodes (e.g., glassy carbon, tungsten, steel, or platinum), sodium metal will be reduced and deposited first onto the inert electrodes, as indicated by its highest redox potential $\left(E_{\mathrm{Na}^{+} / \mathrm{Na}}^{0}=-3.42 \mathrm{vs} . \mathrm{Cl}^{-} / \mathrm{Cl}_{2}(\mathrm{~g})\right)$. In fact, sodium metal is produced by electrolytic decomposition of binary $\mathrm{CaCl}_{2}-\mathrm{NaCl}\left(42-58 \mathrm{~mol} \%, T_{\mathrm{m}}=580{ }^{\circ} \mathrm{C}\right)$ electrolyte at $600^{\circ} \mathrm{C}$ in an industrial-scale Downs cell where sodium metal is preferentially reduced onto an inert steel cathode[10], as suggested by the analysis of standard electrode potentials (Figure 1). In contrast, in the presence of liquid bismuth electrode in ternary $\mathrm{LiCl}-\mathrm{CaCl}_{2}-\mathrm{NaCl}\left(38-35-27 \mathrm{~mol} \%, T_{\mathrm{m}}=450{ }^{\circ} \mathrm{C}\right)$ electrolyte, the preferential deposition of calcium into a liquid bismuth electrode was reported to occur over sodium at $600{ }^{\circ} \mathrm{C}$, due to the stronger interaction (or low thermodynamic activity) of calcium-bismuth $\left(a_{\mathrm{Ca} \text { (in Bi) }} \sim 10^{-11}\right)$ over sodium-bismuth $\left(a_{\mathrm{Na} \text { (in Bi) }} \sim 10^{-5}\right)$.[11]

In this study, the electrochemical properties of liquid bismuth electrodes will be investigated in the multi-component $\mathrm{BaCl}_{2}-\mathrm{LiCl}-\mathrm{CaCl}_{2}-\mathrm{NaCl}$ (16-29-35-20 mol\%) electrolyte 
$\left(T_{\mathrm{m}}=390{ }^{\circ} \mathrm{C}\right.$ ) by characterizing (i) the chemical composition of the discharged electrode that verifies the preferential deposition of barium over calcium and sodium, (ii) the electrode potentials during deposition and removal processes, and (iii) electrochemical impedance spectra at $500-700{ }^{\circ} \mathrm{C}$ to elucidate the overpotential mechanisms of the electrode processes.

\section{EXPERIMENTAL}

\subsection{Electrochemical cell components and assembly}

All the electrochemical cell components were prepared and assembled in an argon-filled glovebox $\left(<1 \mathrm{ppm} \mathrm{O}_{2}\right.$ concentration) to prevent the reactions with moisture and oxygen due to the hygroscopic nature of electrolytes and the high reactivity of electrode materials.

Electrolytes: High-purity (>99.99\%) anhydrous salts of $\mathrm{BaCl}_{2}$ (Alfa Aesar, Product No.13686), LiCl (Alfa Aesar, Product No.13684), $\mathrm{CaCl}_{2}$ (Alfa Aesar, Product No. 44280), and $\mathrm{NaCl}$ (Alfa Aesar, Product No. 35716) were weighed in appropriate quantities, mixed, and premelted to prepare dry, homogenous $\mathrm{BaCl}_{2}-\mathrm{LiCl}-\mathrm{CaCl}_{2}-\mathrm{NaCl}(16-29-36-20 \mathrm{~mol} \%)$ electrolyte. The initially mixed salts ( $400 \mathrm{~g}$ batch) were contained in quartz crucibles (Technical Glass Products), and placed in a stainless steel vacuum chamber in an inert atmosphere. The chamber was evacuated to less than 10 mtorr, heated at $80^{\circ} \mathrm{C}$ for $12 \mathrm{~h}$ and at $230^{\circ} \mathrm{C}$ for $12 \mathrm{~h}$ under vacuum, purged with ultra high-purity argon (Airgas) three times, and heated at $700^{\circ} \mathrm{C}$ for $3 \mathrm{~h}$ under flowing argon atmosphere ( 20 sccm) using a crucible furnace (Mellen, CC-12). After cooling, the premelted electrolytes were ground into a fine powder for electrochemical cell assembly.

Electrodes: Electrodes were prepared from pure bismuth (99.999\%, Alfa Aesar, Product No. 14442) and calcium (99.99\% dendritic pieces, Sigma Aldrich, Product No. 441872). The pure bismuth working electrode was prepared by melting $3.47 \mathrm{~g}$ of bismuth metal in a BN crucible (Saint-Gobain Advanced Ceramics, Product No. AX05) using an induction heater (MTI 
corporation, EQ-SP-15A). The dimensions of the $\mathrm{BN}$ crucible were $12 \mathrm{~mm}$ outer diameter, $8 \mathrm{~mm}$ inner diameter, $19 \mathrm{~mm}$ height, and $15 \mathrm{~mm}$ depth. A tungsten wire (Alfa Aesar, Product No. 10411), $1 \mathrm{~mm}$ in diameter and $47 \mathrm{~cm}$ in length, was inserted into the bismuth working electrode during induction heating to establish electrical contact. The reference electrode was constructed based on two-phase $\mathrm{Ca}-\mathrm{Bi}$ alloys $\left(x_{\mathrm{Ca}}=0.35\right)$ that were prepared and homogenized using an arcmelter (Edmund Bühler GmbH, MAM1). Approximately $4 \mathrm{~g}$ samples of arc-melted Ca-Bi alloy were placed in a BN crucible (same dimensions as the working electrode) and re-melted using the induction heater to establish electrical contact with the tungsten wire. A larger surface area counter electrode ( $\sim 8$ times of the working electrode) was prepared using a single phase $\mathrm{Ca}-\mathrm{Bi}$ alloy $\left(x_{\mathrm{Ca}}=0.15\right)$ in a larger diameter $\mathrm{BN}$ crucible $(25 \mathrm{~mm}$ outer diameter, $22 \mathrm{~mm}$ inner diameter $)$ by gradually adding calcium into liquid bismuth using an induction heater.

Cell assembly: The electrochemical cell was assembled by arranging the electrodes inside an alumina crucible $(56 \mathrm{~mm}$ inner diameter and $100 \mathrm{~mm}$ height; McDanel Advanced Ceramics) and then $160 \mathrm{~g}$ of the electrolyte was added over the electrodes. The assembled electrochemical cell was placed into a stainless steel vacuum chamber, the chamber sealed, and loaded into a crucible furnace. The test chamber was first evacuated and dried following a similar procedure as for preparing the electrolytes to remove the residual moisture from the cell components, and then, heated to the target temperature of $500-700{ }^{\circ} \mathrm{C}$ for electrochemical measurements under inert argon atmosphere.

\subsection{Electrochemical measurements and characterization}

Electrochemical measurements: The electrochemical behavior of the bismuth working electrode was investigated using a standard three-electrode setup for all the electrochemical measurements. The equilibrium potentials of the two-phase $\mathrm{Ca}-\mathrm{Bi}$ reference electrode $\left(x_{\mathrm{Ca}}=0.35\right)$ 
were corrected against the chlorine evolution potential $\left[\mathrm{Cl}^{-} / \mathrm{Cl}_{2}(\mathrm{~g})\right]$ at $500-700{ }^{\circ} \mathrm{C}$ from the literature values, as summarized in Table 2.[1,8] In this article, the electrode potentials of the working electrodes are reported relative to the chlorine evolution potential. The stability of the reference electrode was estimated by measuring a potential difference between the two reference electrodes, which remained less than $\pm 0.2 \mathrm{mV}$ during the electrochemical measurements.

\section{[Table 2]}

At the beginning of each electrochemical deposition experiment at 500,600 , and $700{ }^{\circ} \mathrm{C}$, the pure bismuth working electrodes were held at $0.7 \mathrm{~V}$ versus the reference electrode potential for $1 \mathrm{~h}$ to maintain consistent initial electrode conditions. At this potential, the residual current density remained below $0.1,0.4$, and $1.0 \mathrm{~mA} \mathrm{~cm}^{-2}$ at 500,600 , and $700{ }^{\circ} \mathrm{C}$, respectively. Then, the working electrodes were subjected to discharge-charge (deposition-removal) cycles at constant current densities $j= \pm 25-150 \mathrm{~mA} \mathrm{~cm}^{-2}$ while recording the electrode potential. At selected potentials, the electrode processes were investigated using electrochemical impedance spectroscopy (EIS) by applying a $5 \mathrm{mV}$ amplitude over a $0.01-100000 \mathrm{~Hz}$ frequency range. The collected impedance spectra were fitted to an equivalent circuit model, typically $R(Q(R W))$, where $R$ is a resistor, $Q$ is a constant phase element, and $W$ is a Warburg diffusion element.

Electrode characterization: At the end of electrochemical measurements, the bismuth working electrodes were coulometrically titrated to a target composition and cooled to room temperature for post-mortem analysis. The electrodes were mounted in epoxy, cross-sectioned, polished using silicon carbide emery paper up to 1600 grit with isopropyl alcohol, and ultrasonically cleaned in an isopropyl alcohol bath. The electrodes were examined using a scanning electron microscope (SEM) fitted with an energy dispersive spectrometer (EDS) for chemical and morphological analyses. 


\section{RESULTS AND DISCUSSION}

\subsection{Barium deposition into liquid bismuth}

The liquid bismuth electrode was discharged at $\sim 50 \mathrm{C} \mathrm{g}^{-1}$ under constant current density $j$ $=-100 \mathrm{~mA} \mathrm{~cm}{ }^{-2}$ in $\mathrm{BaCl}_{2}-\mathrm{LiCl}-\mathrm{CaCl}_{2}-\mathrm{NaCl}$ electrolyte solution at $600{ }^{\circ} \mathrm{C}$ prior to cooling to room temperature. Cross-section analysis of the discharged bismuth electrode confirmed barium as the dominant depositing species, accompanied by co-deposition of calcium, according to the elemental X-ray mappings and chemical analysis by SEM-EDS (Figure 3). The solidified electrode was comprised of ternary (Ba-Ca-Bi) intermetallic compounds, embedded in a nearly pure bismuth matrix. The chemical composition of the intermetallic compound was 30-50 mol\% $\mathrm{Ba}, 5-8 \mathrm{~mol} \% \mathrm{Ca}$, and the remaining $\mathrm{Bi}$.

\section{[Figure 3]}

As discussed earlier, the unusual deposition of barium occurs due to the extremely low thermodynamic activity values of barium in bismuth, compared to those of calcium, sodium, and lithium over a substantial composition range, as summarized in Table 3.[5-9] The activity values were estimated using the electromotive force (emf) values $E_{\text {cell }}$ in the literature according to the Nernst equation: $E_{\text {cell }}(\mathrm{V})=-(R T / n F) \ln a_{\mathrm{A}(\mathrm{inBi})}$ at each composition. The estimated activity values of barium in bismuth $a_{\mathrm{Ba} \text { (in Bi) }}$ are much lower than that of calcium by three to four orders of magnitude, which are sufficient to shift the equilibrium potential of $\mathrm{Ba}-\mathrm{Bi}(-2.49 \mathrm{~V})$ more positive than that of $\mathrm{Ca}-\mathrm{Bi}(-2.53 \mathrm{~V})$, switch the deposition sequence (Figure 2), and lead to a preferential barium deposition. As the deposition proceeds, the equilibrium potentials among these alkali/alkaline-earth elements tend to overlap each other, in particular for calcium, leading to the co-deposition of calcium as shown in Figure 3.

\section{[Table 3]}




\subsection{Discharge (deposition) capacity of liquid Bi}

The discharge capacity of the liquid bismuth electrode was estimated under constant current densities $j=-25-150 \mathrm{~mA} \mathrm{~cm}{ }^{-2}$ at $500-700{ }^{\circ} \mathrm{C}$ while measuring the electrode potential as a function of specific charge (Figure 4). In Figure 4, the electrode potential continuously decreases as deposition proceeds, followed by a steep potential drop (nucleation overpotential) due to the nucleation of a solid intermetallic phase at all temperatures. The liquid-state specific capacity of the liquid bismuth was determined at the onset of the steep potential drop.

\section{[Figure 4]}

At $600{ }^{\circ} \mathrm{C}$, the liquid-state specific capacity of the bismuth electrode was in the range of 250-280 $\mathrm{C} \mathrm{g}^{-1}$ for barium and calcium deposition at current densities of $-25-150 \mathrm{~mA} \mathrm{~cm}$ (Figure 4a). Assuming perfect coulombic efficiencies for predominant deposition of barium and calcium at $600{ }^{\circ} \mathrm{C}$, this specific discharge capacity was converted to the mole fraction $x_{\mathrm{Ba}+\mathrm{Ca}}$ by Faraday's law according to:

$$
x_{\mathrm{Ba}+\mathrm{Ca}}=\left(\frac{m_{\mathrm{Bi}} n F}{M_{\mathrm{Bi}}|j| A t}+1\right)^{-1}
$$

, where the mass of bismuth $m_{\mathrm{Bi}}=3.47 \mathrm{~g}$, the molecular weight of bismuth $M_{\mathrm{Bi}}=209 \mathrm{~g} \mathrm{~mol}^{-1}$, the nominal electrode surface area $A=0.50 \mathrm{~cm}^{2}$, and $t$ is the elapsed time during electrolysis. Using this relation, the bismuth electrode was found to accommodate up to $21-23 \mathrm{~mol} \%$ of barium and calcium in liquid states at $-25-150 \mathrm{~mA} \mathrm{~cm}^{-2}$.

To a first approximation, the obtained discharge capacity was compared to the theoretical solubility limit of barium or calcium in liquid bismuth $\left(30 \mathrm{~mol} \% \mathrm{Ba}\right.$ and $25 \mathrm{~mol} \% \mathrm{Ca}$ at $\left.600{ }^{\circ} \mathrm{C}\right)$ [12], achieving approximately $70-77 \%$ of the theoretical solubility limit. Such a large liquid-state discharge capacity of bismuth is thought to originate from a high liquid-state solubility as well as 
the rapid mass transport properties of liquid metal electrodes. For these reasons, the discharge capacity will increase at higher temperatures due to the increased liquid-state solubility and enhanced mass transport properties, as presented in Figure $4 \mathrm{~d}$ at constant current $j=-150 \mathrm{~mA}$ $\mathrm{cm}^{-2}$.

At each temperature, the liquid-state discharge capacity of bismuth decreased successively as the cathodic current density increased from -25 to $-150 \mathrm{~mA} \mathrm{~cm}{ }^{-2}$ (Figure $4 \mathrm{a}-4 \mathrm{c}$ ). The decreased discharge capacity at higher current densities can be understood, in part, by considering that the rate of deposition at the electrode-electrolyte interface is faster than the diffusion rate of reduced species into the bismuth electrode. When the deposition proceeds beyond the solubility limit near the electrode-electrolyte interface, the intermetallic compounds will nucleate and may segregate near the interface due to the lower density of intermetallic

compounds (e.g., $6.33 \mathrm{~g} \mathrm{~cm}^{-3}$ for $\mathrm{Ca}_{11} \mathrm{Bi}_{10}$ and $6.30 \mathrm{~g} \mathrm{~cm}^{-3}$ for $\mathrm{Ba}_{5} \mathrm{Bi}_{3}$ at $25^{\circ} \mathrm{C}$ ) versus the density of liquid bismuth $\left(10.1 \mathrm{~g} \mathrm{~cm}^{-3}\right.$ at $\left.T_{\mathrm{m}, \mathrm{Bi}}=271^{\circ} \mathrm{C}\right)$.

\subsection{Coulombic efficiencies and the chemical reversibility of Bi electrode}

The coulombic efficiency of the electrode reactions into liquid bismuth was tested by discharge-charge (deposition-removal) cycles of the bismuth electrode at various constant current densities $j= \pm 25-150 \mathrm{~mA} \mathrm{~cm}^{-2}$ at $600{ }^{\circ} \mathrm{C}$. Excellent coulombic efficiencies (>99\%) were observed at all current densities, as shown in Figure 5 at a current density of $50 \mathrm{~mA} \mathrm{~cm}^{-2}$, suggesting that the electrode reactions are chemically reversible during the deposition-removal cycles.

\section{[Figure 5]}

While excellent round-trip coulombic efficiencies (> 99\%) were also obtained at $500{ }^{\circ} \mathrm{C}$, somewhat lower coulombic efficiencies (96-99\%) were observed during the deposition-removal 
cycles at $700{ }^{\circ} \mathrm{C}$. At $700{ }^{\circ} \mathrm{C}$, the coulombic efficiencies tend to decrease at lower current densities possibly due to the presence of side reactions between the electrodes and the electrolyte that can promote a self-discharge reaction. A number of studies in the literature indicate that the coulombic loss may originate from the dissolution reaction of alkali/alkaline-earth metals in the molten salt electrolytes, which can provide self-discharge mechanisms through the transport of electroactive components and/or promote the electronic conductivity of the electrolyte.[13-17]

\subsection{Kinetic behavior}

During electrolysis, the electrode potential deviated from the open-circuit potential at each electrode composition due to current-dependent overpotential mechanisms of charge transfer $\eta_{\mathrm{ct}}$, mass transport $\eta_{\mathrm{mt}}$, and ohmic $\eta_{\mathrm{ohm}}$ losses according to:

$$
\eta_{\mathrm{total}}=\eta_{\mathrm{ct}}+\eta_{\mathrm{mt}}+\eta_{\mathrm{ohm}}
$$

At $600{ }^{\circ} \mathrm{C}$, the total overpotentials were analyzed based upon the electrode potential obtained during the deposition-removal cycles at various current densities (Figure 6a) by constructing current-potential $(I-V)$ characteristics (Figure 6b), and the relative contribution of each overpotential mechanism was investigated using EIS techniques (Figure 7).

For this analysis, the specific charge was converted to the mole fraction of barium and calcium $x_{\mathrm{Ba}+\mathrm{Ca}}$ using the Faraday's law in equation (3) because nearly perfect coulombic efficiencies were observed in deposition/removal cycles at $600{ }^{\circ} \mathrm{C}$. In addition, the open-circuit potential of the electrode $E_{\mathrm{OCP}}$ was obtained after the electrode was coulometrically titrated at selected compositions and held under an open-circuit condition for 3600s to allow the electrode composition to homogenize (open circles in Figure 6a).

\section{[Figure 6]}

\subsubsection{Total overpotential analysis}


Figure 6a displays the electrode potential as a function of mole fraction at various current densities at $600{ }^{\circ} \mathrm{C}$ in deposition-removal cycles. It is observed that the overpotential $\eta(=E-$ $\left.E_{\mathrm{OCP}}\right)$ increases as current density increases from $25 \mathrm{~mA} \mathrm{~cm}$ to $150 \mathrm{~mA} \mathrm{~cm}$. The electrode potential was analyzed as a function of current density $j$ (Figure 6b), based upon the currentdependent electrode potentials at selected electrode compositions $\left(x_{\mathrm{Ba}+\mathrm{Ca}}=0.05,0.10,0.15\right.$, and $0.20)$, presented as vertical dashed lines in Figure 6a.

As presented in Figure $6 \mathrm{~b}$, the linear $I-V$ characteristics were observed for the liquid electrodes up to $x_{\mathrm{Ba}+\mathrm{Ca}}=0.20$. From the linear slope $(d E / d j)$ by linear regression at each electrode composition, the total area specific resistance $A \cdot R_{\mathrm{tot}}$ was estimated, as summarized in Table 4 . As the total resistance $R_{\mathrm{tot}}$ is comprised of charge transfer $R_{\mathrm{ct}}$, mass transport $R_{\mathrm{mt}}$, and ohmic resistances $R_{\text {ohm }}$, the overpotential relation can be approximated as follows:

$$
\eta_{\mathrm{total}} \cong A j R_{\mathrm{tot}} \cong A j\left(R_{\mathrm{ct}}+R_{\mathrm{mt}}+R_{\mathrm{ohm}}\right) .
$$

In this analysis, the total area specific ohmic resistances $A \cdot R_{\text {total }}$ decreased from $0.89 \Omega \mathrm{cm}^{2}$ to $0.69 \Omega \mathrm{cm}^{2}$ upon increasing the concentration of barium and calcium. As the ohmic resistance remains virtually constant in three-electrode cells, this result suggests that charge transfer or mass transport resistances change dynamically depending upon the state of discharge (deposition) during electrolysis.

\section{[Table 4]}

\subsubsection{Charge transfer resistance by EIS}

To elucidate the relative contributions to the total resistance by charge transfer, mass transport, and ohmic resistances, electrochemical impedance spectra were collected at selected compositions at $600{ }^{\circ} \mathrm{C}$ (Figure 7a). From the equivalent circuit model fitting results, the ohmic 
resistance (the high frequency semicircle intercept) and the charge transfer resistance (the semicircle width) were evaluated, as summarized in Table 5.

\section{[Figure 7]}

\section{[Table 5]}

At $600{ }^{\circ} \mathrm{C}$, the charge transfer resistance $A \cdot R_{\mathrm{ct}}$ decreased from 0.64 to $0.51 \Omega \mathrm{cm}^{2}$ as the electrode potential decreased, i.e., as the concentration of barium and calcium $x_{\mathrm{Ba}+\mathrm{Ca}}$ increased from 0.05 to 0.20 (Figure 7a and Table 5). The trend of decreased charge transfer resistance at higher concentration of barium and calcium was also found at both 500 and $700{ }^{\circ} \mathrm{C}$ (Figure $7 \mathrm{~b}$ and Table 5). By contrast, the ohmic resistance was independent of electrode potential and was small $\left(0.11 \Omega \mathrm{cm}^{2}\right)$, as is typical for a three-electrode setup. At higher temperatures, the ohmic resistance decreased from $0.14 \Omega \mathrm{cm}^{2}$ at $500{ }^{\circ} \mathrm{C}$ to $0.10 \Omega \mathrm{cm}^{2}$ at $700{ }^{\circ} \mathrm{C}$ due to increased ionic conductivity of the electrolyte, as shown in Figure 7c.

The decrease of charge transfer resistance at higher concentration of barium and calcium was in accordance with the trend found in total resistance at $600{ }^{\circ} \mathrm{C}$ (Table 4), suggesting the charge transfer resistance to be the main contributor to the change in the total resistance. At the mole fraction $x_{\mathrm{Ba}+\mathrm{Ca}}=0.05$, the electrode has the total area specific resistance $A \cdot R_{\text {total }}$ of $0.89 \Omega$ $\mathrm{cm}^{2}$, which includes charge transfer resistance $A \cdot R_{\mathrm{ct}}$ of $0.64 \Omega \mathrm{cm}^{2}(70 \%)$ and ohmic resistance of $0.11 \Omega \mathrm{cm}^{2}(10 \%)$ with the remaining resistance $(20 \%)$ attributable to mass transport limitations $\left(R_{\mathrm{mt}}=R_{\mathrm{total}}-R_{\mathrm{ct}}-R_{\mathrm{ohm}}\right)$ at $600{ }^{\circ} \mathrm{C}$. Based on our analysis, the overpotential of the liquid bismuth electrode is thought to be dominated by the charge transfer mechanism $(\sim 70-80 \%)$ during electrolysis.

From the charge transfer resistance obtained by EIS at small overpotentials $(5 \mathrm{mV})$, the exchange current density $j_{0}$ was estimated according to[18]: 


$$
j_{0}=\frac{R T}{n F A R_{\mathrm{ct}}}
$$

Using this relation, the exchange current density of the liquid bismuth electrode for barium and calcium deposition was in the range of $40-50 \mathrm{~mA} \mathrm{~cm}^{-2}$ at $500^{\circ} \mathrm{C}, 60-90 \mathrm{~mA} \mathrm{~cm}^{-2}$ at $600{ }^{\circ} \mathrm{C}$, and $90-130 \mathrm{~mA} \mathrm{~cm}^{-2}$ at $700^{\circ} \mathrm{C}$ (Table 5). As is expected for kinetically-driven interfacial processes, the exchange current density increased at higher temperatures, i.e., lower charge transfer resistance at high temperatures. The estimated exchange current density for co-deposition of barium and calcium $\left(60-90 \mathrm{~mA} \mathrm{~cm}^{-2}\right)$ was lower than that reported in the literature for selective deposition of calcium $\left(140-260 \mathrm{~mA} \mathrm{~cm}^{-2}\right)$ at $600{ }^{\circ} \mathrm{C}[11]$, indicating that the charge transfer reaction of barium species is kinetically less facile compared to calcium.

\section{CONCLUSIONS}

We demonstrated the unique deposition behavior of barium into a bismuth electrode from a multi-component molten salt electrolyte $\left(\mathrm{BaCl}_{2}-\mathrm{LiCl}-\mathrm{CaCl}_{2}-\mathrm{NaCl}\right)$ due to the strong atomic interactions between barium and bismuth compared to calcium, sodium and lithium. By exploiting the differential interactions of electroactive species with liquid bismuth, it was possible to separate conventionally non-separable barium species from the electrolyte solution. These findings can be directly employed in separating out radiotoxic nuclear fission products such as $\mathrm{Ba}, \mathrm{Sr}$, and $\mathrm{Cs}$ from used nuclear fuels. In electrochemical separation processes of used nuclear fuel for actinides, these alkali/alkaline-earth metals are readily dissolved and accumulated in the molten salt electrolyte (e.g., LiCl-KCl eutectic) during electrorefining of actinide elements (e.g., uranium) due to their high elemental reactivity, resulting in a wastage of chloride electrolytes that require further processing and separation. Employing strongly interacting liquid metal electrodes, the separation of the alkali/alkaline-earth fission products is feasible, as demonstrated by the separation of barium from the molten salt electrolyte. 
The unexpected barium deposition was analyzed using the Nernst equation by considering the thermodynamic activity values of each cation species in the liquid bismuth - the key material properties in controlling the deposition potentials and enabling the separation of barium. Interestingly, the bismuth electrode exhibited highly reversible electrode reactions during the deposition processes of barium and calcium, confirmed by high coulombic efficiencies (>99\%); charge transfer resistance was the most significant contributor to the overpotentials according to the analysis of electrochemical impedance spectra. 


\section{Author Information}

\section{Corresponding Author}

*E-mail: huk29@psu.edu. Telephone: 814-865-3117. Fax: 814-865-2917.

\section{Author Contributions}

The manuscript was written through contributions of all authors. All authors have given approval to the final version of the manuscript.

\section{Funding Sources}

US Department of Energy, Office of Nuclear Energy

\section{Acknowledgment}

The financial support of the US Department of Energy, Office of Nuclear Energy's Nuclear Energy University Programs (Award No. DE-NE0008425) is gratefully acknowledged. 


\section{FIGURES.}

Figure 1. Standard electrode potentials of selected alkali/alkaline-earth elements vs. $\mathrm{Cl}^{-} / \mathrm{Cl}_{2}(\mathrm{~g})$, calculated based on the standard free energy of formation of pure chlorides at $600^{\circ} \mathrm{C}$.[1]

Figure 2. Equilibrium potentials of redox couples in the bismuth electrode (open triangle) at constant mole fraction $x_{\mathrm{A}(\mathrm{in} \mathrm{Bi})}=0.05$, compared to standard electrode potential (open circle) at $600^{\circ} \mathrm{C}$. The line between the two equilibrium potentials of each species represents the shift in electrode potential due to the activity in the bismuth electrode.

Figure 3. SEM image of the Bi electrode discharged at $\sim 50 \mathrm{C} \mathrm{g}^{-1}$ from $\mathrm{BaCl}_{2}-\mathrm{LiCl}_{-}-\mathrm{CaCl}_{2}-\mathrm{NaCl}$ electrolyte using a constant current $\left(-100 \mathrm{~mA} \mathrm{~cm}{ }^{-2}\right)$ at $600{ }^{\circ} \mathrm{C}$ and elemental X-ray mappings of $\mathrm{Ba}, \mathrm{Ca}$, and $\mathrm{Bi}$.

Figure 4. Electrode potential of bismuth electrode as a function of specific charge under constant current density $j=-25-150 \mathrm{~mA} \mathrm{~cm}{ }^{-2}$ in $\mathrm{LiCl}-\mathrm{NaCl}-\mathrm{CaCl}_{2}-\mathrm{BaCl}_{2}$ electrolyte at (a) $600{ }^{\circ} \mathrm{C}$, (b) $500{ }^{\circ} \mathrm{C}$, (c) $700{ }^{\circ} \mathrm{C}$, and (d) $500-700^{\circ} \mathrm{C}$ and $j=-150 \mathrm{~mA} \mathrm{~cm}{ }^{-2}$.

Figure 5. Deposition-removal cycle of liquid bismuth electrode in $\mathrm{BaCl}_{2}-\mathrm{LiCl}-\mathrm{CaCl}_{2}-\mathrm{NaCl}$ at $600^{\circ} \mathrm{C}$ under a constant current density $j= \pm 50 \mathrm{~mA} \mathrm{~cm}^{-2}$.

Figure 6. (a) Electrode potential as a function mole fraction of barium and calcium $x_{\mathrm{Ba}+\mathrm{Ca}}$ at various current densities $j= \pm 25,50,100,150 \mathrm{~mA} \mathrm{~cm}^{-2}$. The open circuit potentials (open circle) 
were measured by coulometric titration at selected compositions at $600{ }^{\circ} \mathrm{C}$, and (b) electrode potential as a function of current density $j$ upon deposition and removal at $600{ }^{\circ} \mathrm{C}$.

Figure 7. Electrochemical impedance spectra of bismuth electrode at selected mole fractions $x_{\mathrm{Ca}+\mathrm{Ba}}$ at (a) $600{ }^{\circ} \mathrm{C}$, with a schematic equivalent circuit $R(Q(R W))$ in the inset used to fit the data, (b) $700{ }^{\circ} \mathrm{C}$, and (c) $500-700{ }^{\circ} \mathrm{C}$. 


\section{TABLES.}

Table 1. The activity of alkali/alkaline-earths $\mathrm{A}(\mathrm{A}=\mathrm{Ba}, \mathrm{Li}, \mathrm{Ca}$, or $\mathrm{Na})$ in liquid bismuth $a_{\mathrm{A}(\mathrm{in} \mathrm{Bi})}$ at a constant mole fraction $x_{\mathrm{A}(\mathrm{in} \mathrm{Bi})}=0.05$, standard electrode potential $E^{0}$ for each redox couple $\left(\mathrm{A}^{n+} / \mathrm{A}\right)$, and the equilibrium potential of bismuth $E_{\mathrm{eq}}$ at $600{ }^{\circ} \mathrm{C} .[5-9]$

\begin{tabular}{ccccc}
\hline $\mathrm{A}^{n+} / \mathrm{A}$ & $a_{\mathrm{A}(\text { in Bi }}$ & $E^{0} / \mathrm{V}$ & $-(R T / n F) \ln a_{\mathrm{A}(\text { in Bi })} / \mathrm{V}$ & $E_{\text {eq }} / \mathrm{V}$ \\
\hline $\mathrm{Ba}^{2+} / \mathrm{Ba}$ & $3.7 \times 10^{-15^{*}}$ & -3.74 & 1.25 & -2.49 \\
$\mathrm{Li}^{+} / \mathrm{Li}$ & $2.5 \times 10^{-6}$ & -3.49 & 0.48 & -3.01 \\
$\mathrm{Ca}^{2+} / \mathrm{Ca}$ & $3.7 \times 10^{-11}$ & -3.44 & 0.90 & -2.53 \\
$\mathrm{Na}^{+} / \mathrm{Na}$ & $1.6 \times 10^{-5}$ & -3.42 & 0.42 & -3.01 \\
\hline
\end{tabular}

$*$ The activity of $\mathrm{Ba}$ in $\mathrm{Bi}$ was estimated by extrapolating the experimental results at $850{ }^{\circ} \mathrm{C}$ using the temperature coefficient of emf $\left(d E_{\text {cell }} / d T\right)$ obtained from a proxy Ca-Bi system $(0.18 \mathrm{mV}$ $\left.\mathrm{K}^{-1}\right) \cdot[8,9]$

Table 2. Equilibrium electrode potential of two-phase $\mathrm{Ca}-\mathrm{Bi}\left(x_{\mathrm{Ca}(\mathrm{in} \mathrm{Bi})}=0.35\right)$ reference electrode versus $\mathrm{Cl}^{-} / \mathrm{Cl}_{2}(\mathrm{~g})$ at $500-700{ }^{\circ} \mathrm{C}$. $[1,8]$

\begin{tabular}{cc}
\hline $\mathrm{T} /{ }^{\circ} \mathrm{C}$ & $E_{\mathrm{eq}} / \mathrm{V}$ \\
\hline 500 & -2.707 \\
600 & -2.652 \\
700 & -2.598 \\
\hline
\end{tabular}


Table 3. The activity values of alkali/alkaline-earths $\mathrm{A}(\mathrm{A}=\mathrm{Li}, \mathrm{Na}, \mathrm{Ca}$, or $\mathrm{Ba})$ in liquid bismuth $a_{\mathrm{A}(\mathrm{in} \mathrm{Bi})}$ at various mole fractions $x_{\mathrm{A}(\text { in Bi) }}$ at $600{ }^{\circ} \mathrm{C}$.[5-9]

\begin{tabular}{c|cccc}
\hline$x_{\mathrm{A}(\text { in Bi })}$ & $a_{\mathrm{Li}(\text { in Bi })}$ & $a_{\mathrm{Na}(\text { in Bi })}$ & $a_{\mathrm{Ca}(\text { in Bi })}$ & $a_{\mathrm{Ba}(\text { in Bi })}{ }^{* *}$ \\
\hline 0.05 & $2.5 \times 10^{-6}$ & $1.6 \times 10^{-6}$ & $3.7 \times 10^{-11}$ & $3.7 \times 10^{-15}$ \\
0.10 & $5.8 \times 10^{-6}$ & $3.9 \times 10^{-5}$ & $1.5 \times 10^{-10}$ & $1.1 \times 10^{-14}$ \\
0.15 & $1.0 \times 10^{-5}$ & $7.1 \times 10^{-5}$ & $2.7 \times 10^{-10}$ & $3.7 \times 10^{-14}$ \\
0.20 & $1.5 \times 10^{-5}$ & $1.2 \times 10^{-4}$ & $3.8 \times 10^{-10}$ & $1.5 \times 10^{-13}$ \\
\hline
\end{tabular}

**: The activity values of $\mathrm{Ba}$ in $\mathrm{Bi}$ at $850^{\circ} \mathrm{C}$ were extrapolated using the temperature coefficient of emf values $\left(d E_{\text {cell }} / d T\right)$ from a proxy Ca-Bi system at each composition. [8, 9]

Table 4. Open-circuit potential $E_{\mathrm{OCP}}$ and the total area specific resistance $A \cdot R_{\text {total }}\left(A=0.50 \mathrm{~cm}^{2}\right)$ of the bismuth electrode at each mole fraction $x_{\mathrm{Ba}+\mathrm{Ca}}$ at $600{ }^{\circ} \mathrm{C}$.

\begin{tabular}{ccc}
\hline$x_{\mathrm{Ba}+\mathrm{Ca}}$ & $E_{\mathrm{OCP}} / \mathrm{V}$ & $A \cdot R_{\mathrm{total}} / \Omega \mathrm{cm}^{2}$ \\
\hline 0.05 & -2.53 & 0.89 \\
0.10 & -2.56 & 0.80 \\
0.15 & -2.60 & 0.71 \\
0.20 & -2.62 & 0.69 \\
\hline
\end{tabular}


Table 5. The estimated area-specific charge transfer resistance $A \cdot R_{\mathrm{ct}}\left(A=0.50 \mathrm{~cm}^{2}\right)$, based on the equivalent circuit model $R(Q(R W))$ fit results to the impedance spectra, and the exchange current density $j_{0}$ at $500-700{ }^{\circ} \mathrm{C}$.

\begin{tabular}{|c|c|c|c|c|c|c|}
\hline \multirow[b]{2}{*}{$x_{\mathrm{Ba}+\mathrm{Ca}}$} & \multicolumn{3}{|c|}{$A \cdot R_{\underline{c t}} / \Omega \mathrm{cm}^{2}$} & \multicolumn{3}{|c|}{$\dot{L}_{0} / \mathrm{mA} \mathrm{cm}^{-2}$} \\
\hline & $500{ }^{\circ} \mathrm{C}$ & $600^{\circ} \mathrm{C}$ & $700{ }^{\circ} \mathrm{C}$ & $500{ }^{\circ} \mathrm{C}$ & $600^{\circ} \mathrm{C}$ & $700{ }^{\circ} \mathrm{C}$ \\
\hline 0.05 & 0.91 & 0.64 & 0.50 & 36 & 59 & 85 \\
\hline 0.10 & 0.66 & - & 0.41 & 51 & - & 100 \\
\hline 0.15 & 0.72 & 0.59 & 0.35 & 46 & 64 & 120 \\
\hline 0.20 & - & 0.51 & 0.32 & 一 & 73 & 130 \\
\hline 0.25 & - & 0.42 & 0.31 & - & 89 & 130 \\
\hline
\end{tabular}




\section{REFERENCES}

[1] HSC Chemistry 5.1, Outokumpu Research Oy, Finland, 2002.

[2] Electrometallurgical Techniques for DOE Spent Fuel Treatment: Final Report, National Academy Press, Washington, D.C., 2000.

[3] M.F. Simpson, Projected Salt Waste Production from a Commercial Pyroprocessing Facility, Science and Technology of Nuclear Installations (2013) Article number: 945858.

[4] H. Kim, D.A. Boysen, J.M. Newhouse, B.L. Spatocco, B. Chung, P.J. Burke, D.J. Bradwell, K. Jiang, A.A. Tomaszowska, K.L. Wang, W.F. Wei, L.A. Ortiz, S.A. Barriga, S.M. Poizeau, D.R. Sadoway, Liquid Metal Batteries: Past, Present, and Future, Chemical Reviews 113(3) (2013) 2075-2099.

[5] W. Weppner, R.A. Huggins, Thermodynamic Properties of Intermetallic Systems LithiumAntimony and Lithium-Bismuth, Journal of the Electrochemical Society 125(1) (1978) 7-14.

[6] M.S. Foster, S.E. Wood, C.E. Crouthamel, THERMODYNAMICS OF BINARY ALLOYS .I. LITHIUM-BISMUTH SYSTEM, Inorganic Chemistry 3(10) (1964) 1428-\&.

[7] M. Iwase, S. Sugino, E. Ichise, Determination of the thermodynamic properties of liquid Na$\mathrm{Tl}, \mathrm{Na}-\mathrm{Pb}$ and $\mathrm{Na}-\mathrm{Bi}$ alloys by emf measurements, High Temperature Materials and Processes $6(3 \& 4)$ (1984) 143-153.

[8] H. Kim, D.A. Boysen, D.J. Bradwell, B.C. Chung, K. Jiang, A.A. Tomaszowska, K.L. Wang, W.F. Wei, D.R. Sadoway, Thermodynamic Properties of Calcium-Bismuth Alloys Determined by Emf Measurements, Electrochimica Acta 60 (2012) 154-162.

[9] J. Delcet, A. Delgado-Brune, J.J. Egan, Coulometric Titrations Using CaF2 and BaF2 Solid Electrolytes to Study Alloy Phases, Calculation of Phase Diagrams and Thermochemistry of Alloy Phases 9B(4) (1979) 275-287.

[10] T. Eggeman, S. Updated by, Sodium and Sodium Alloys, Kirk-Othmer Encyclopedia of Chemical Technology, John Wiley \& Sons, Inc.2000.

[11] H. Kim, D.A. Boysen, T. Ouchi, D.R. Sadoway, Calcium-Bismuth Electrodes for Largescale Energy Storage (Liquid Metal Batteries), Journal of Power Sources 241 (2013) 239-248. [12] ASM Alloy Phase Diagrams Database, ASM International, Materials Park, OH, 2006. [13] H.R. Bronstein, M.A. Bredig, THE ELECTRICAL CONDUCTIVITY OF SOLUTIONS OF ALKALI METALS IN THEIR MOLTEN HALIDES, Journal of the American Chemical Society 80(9) (1958) 2077-2081.

[14] A.S. Dworkin, Bronstei.Hr, M.A. Bredig, ELECTRICAL CONDUCTIVITY OF SOLUTIONS OF METALS IN THEIR MOLTEN HALIDES .8. ALKALINE EARTH METAL SYSTEMS, Journal of Physical Chemistry 70(7) (1966) 2384-\&.

[15] E.A. Ukshe, N.G. Bukun, The Dissolution of Metals in Fused Halides, Russian Chemical Reviews 30(2) (1961) 90-107.

[16] G.M. Haarberg, J. Thonstad, Electrochemical Properties of Metal-Molten Salt Mixtures, Journal of Applied Electrochemistry 19(6) (1989) 789-801.

[17] G.M. Haarberg, K.S. Osen, J. Thonstad, R.J. Heus, J.J. Egan, MEASUREMENT OF ELECTRONIC CONDUCTION IN CRYOLITE ALUMINA MELTS AND ESTIMATION OF ITS EFFECT ON CURRENT EFFICIENCY, Metallurgical Transactions B-Process Metallurgy 24(5) (1993) 729-735.

[18] A.J. Bard, L.R. Faulkner, Electrochemical Methods: Fundamentals and Applications, Wiley, New York, 2001. 
Table of Contents Graphic (TOC)

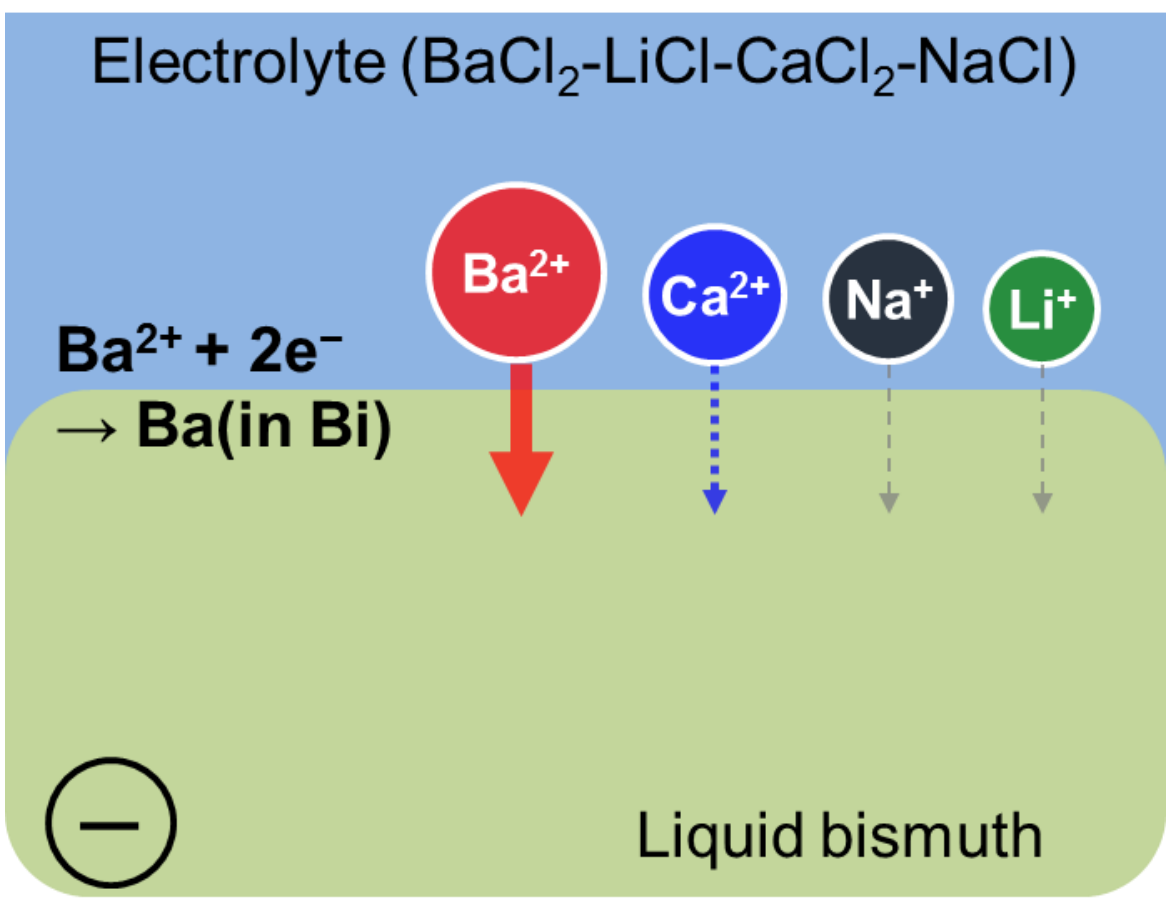




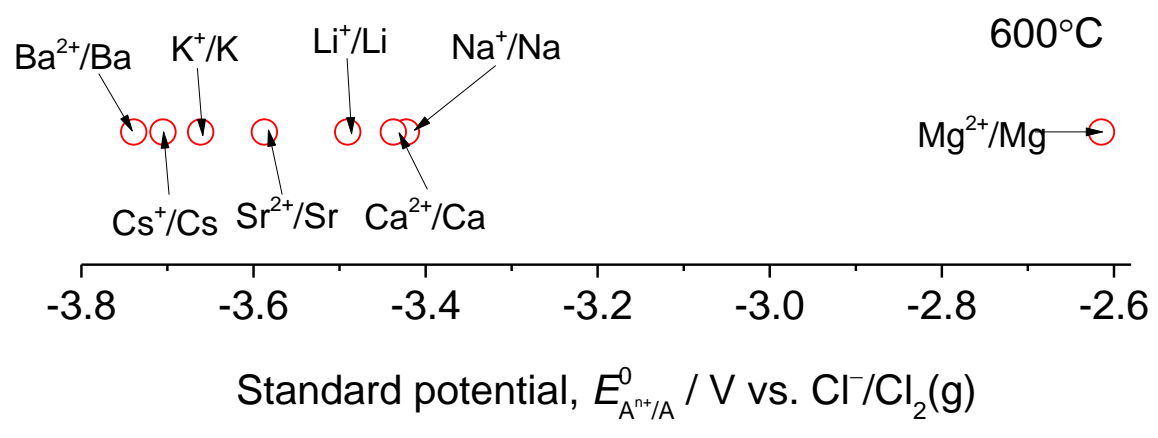

Figure 1.

$600^{\circ} \mathrm{C}$

(1) Standard potential

$\gg$ Equil. potential of A-Bi $\left.\left(x_{\mathrm{A}(\mathrm{in} \text { Bi }}\right)=0.05\right)$

\section{Deposition sequence}
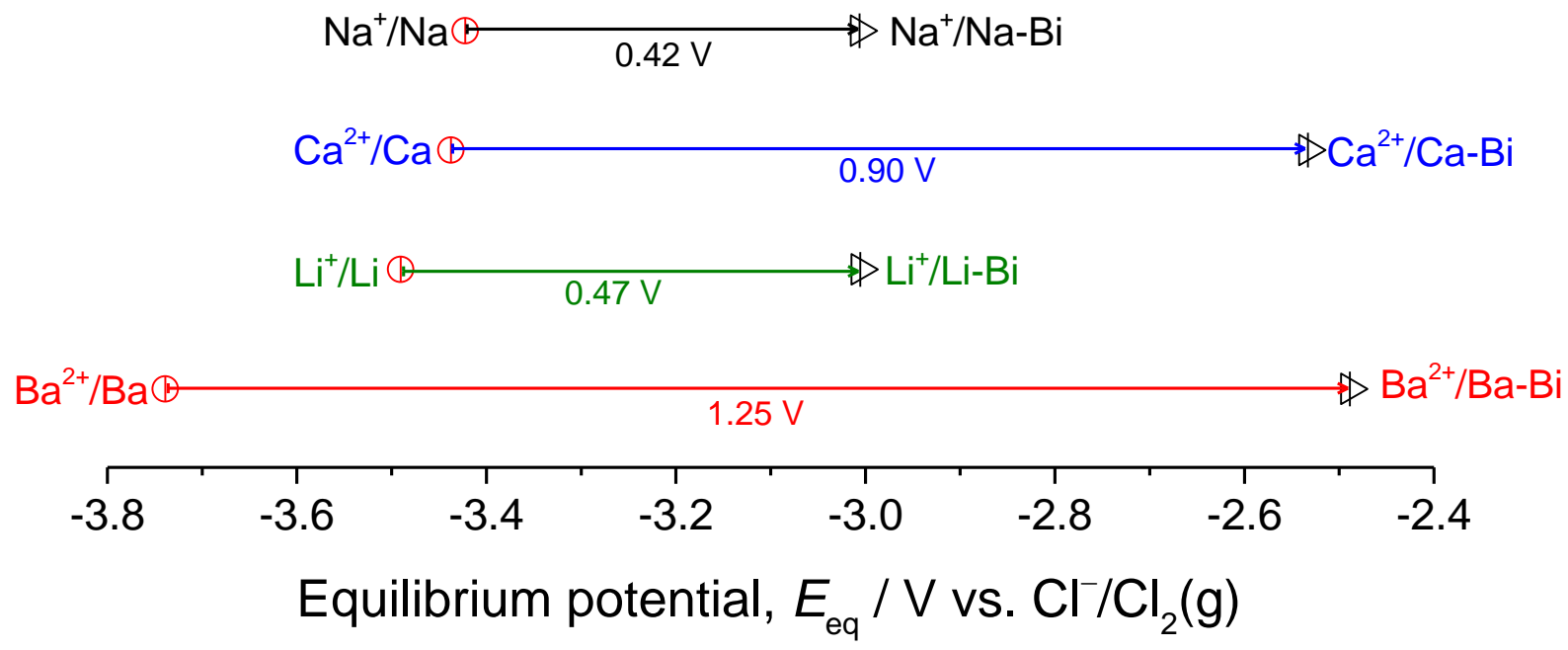

Figure 2. 

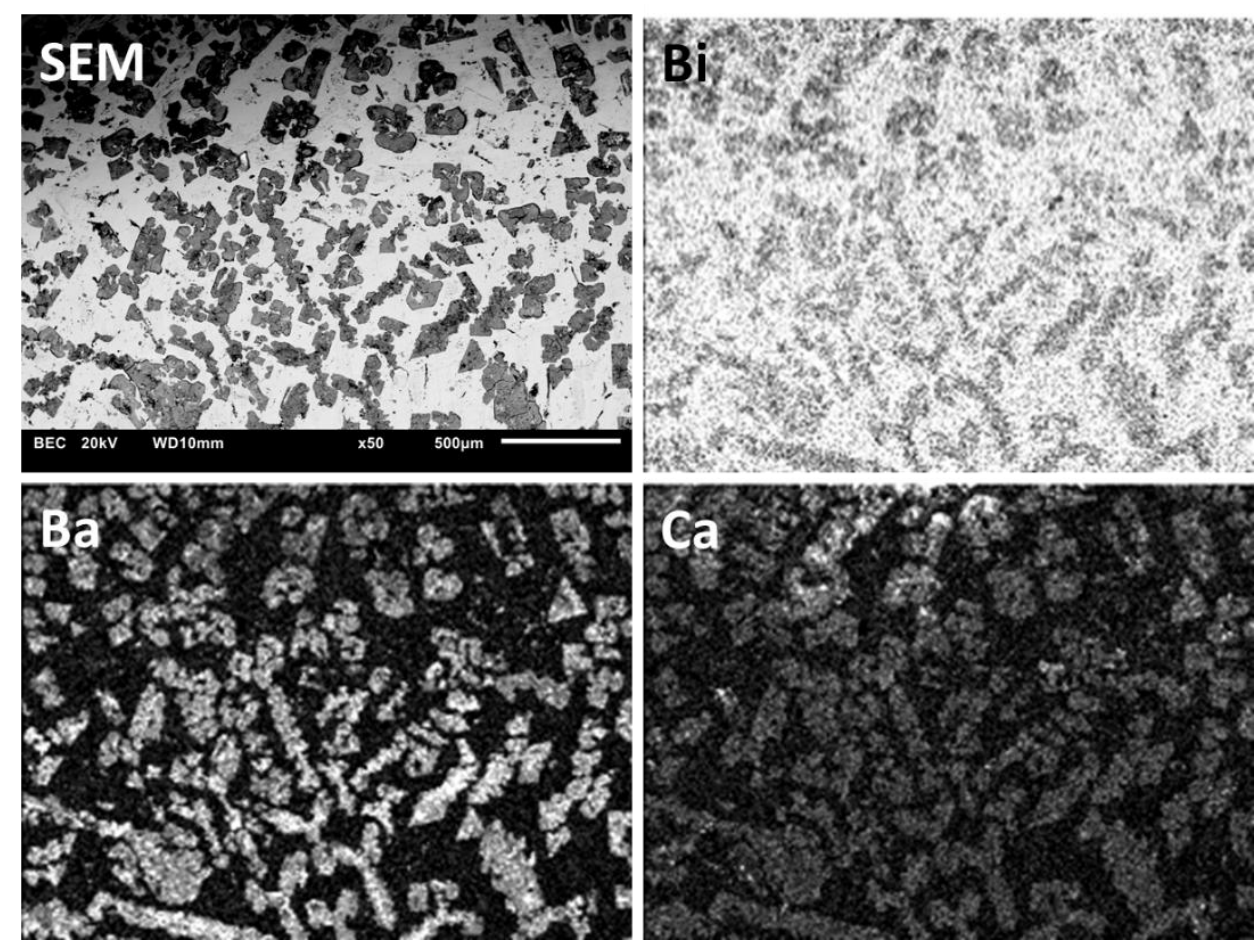

Figure 3. 


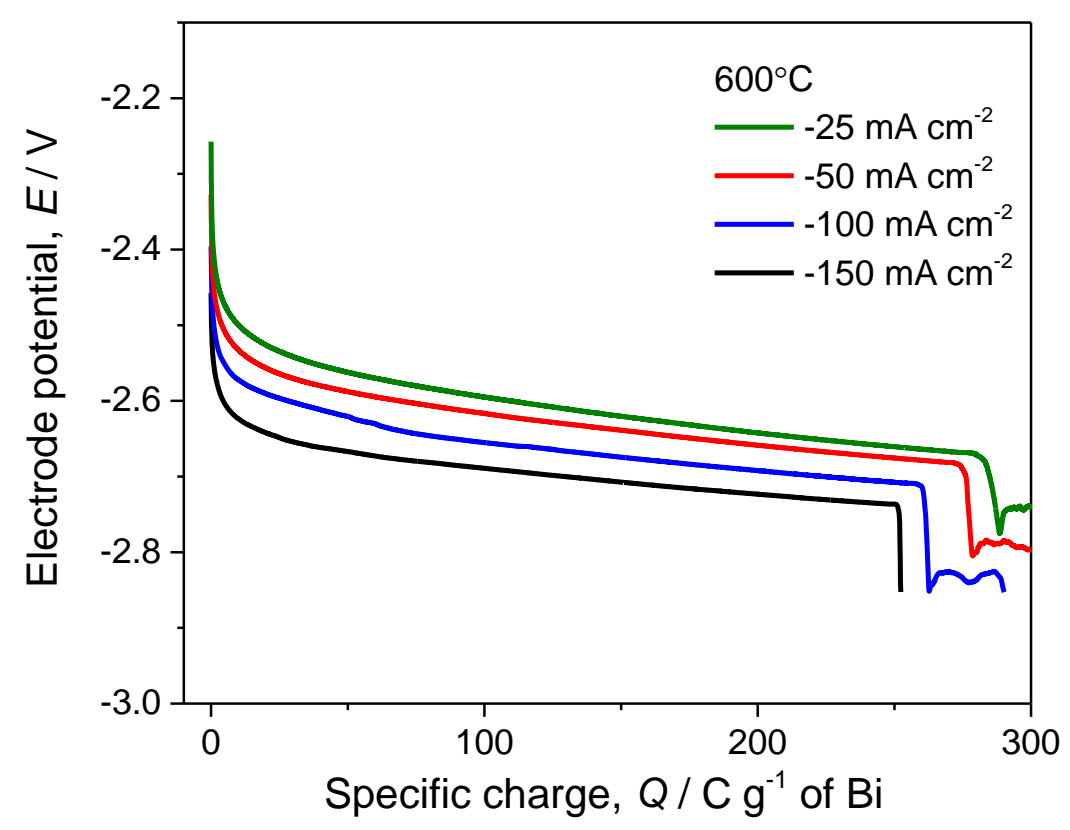

Figure $4 a$.

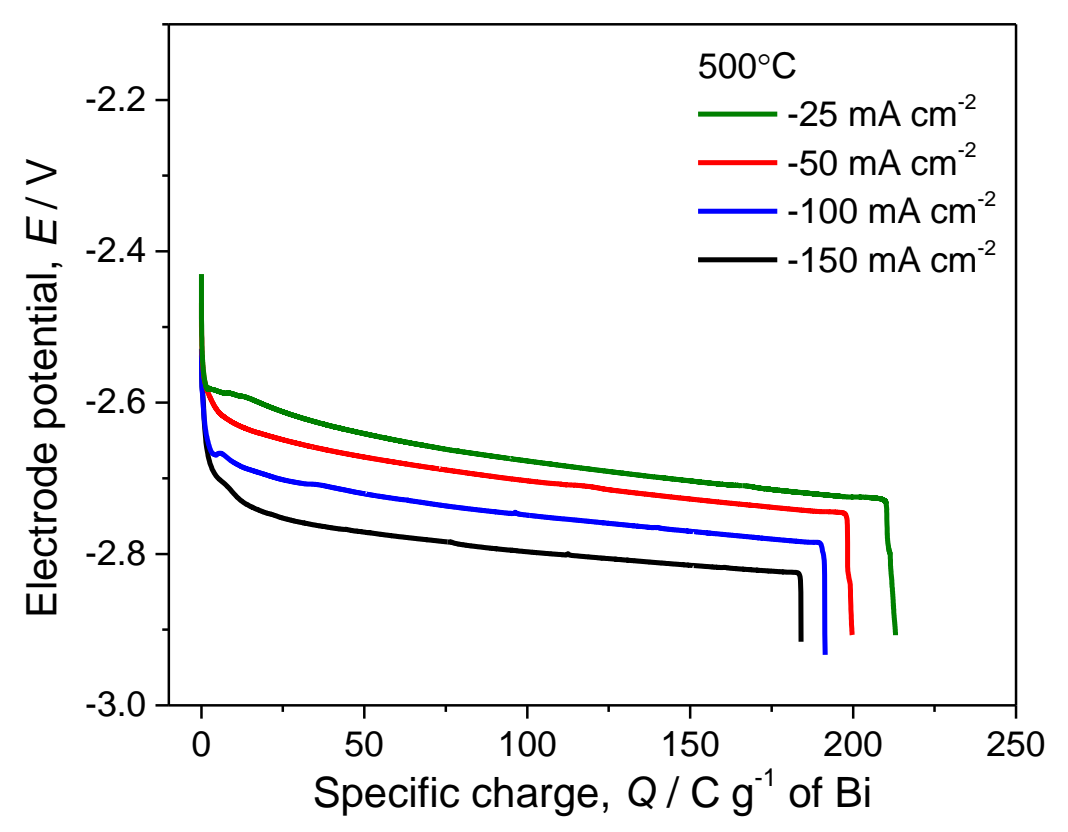

Figure 4b. 


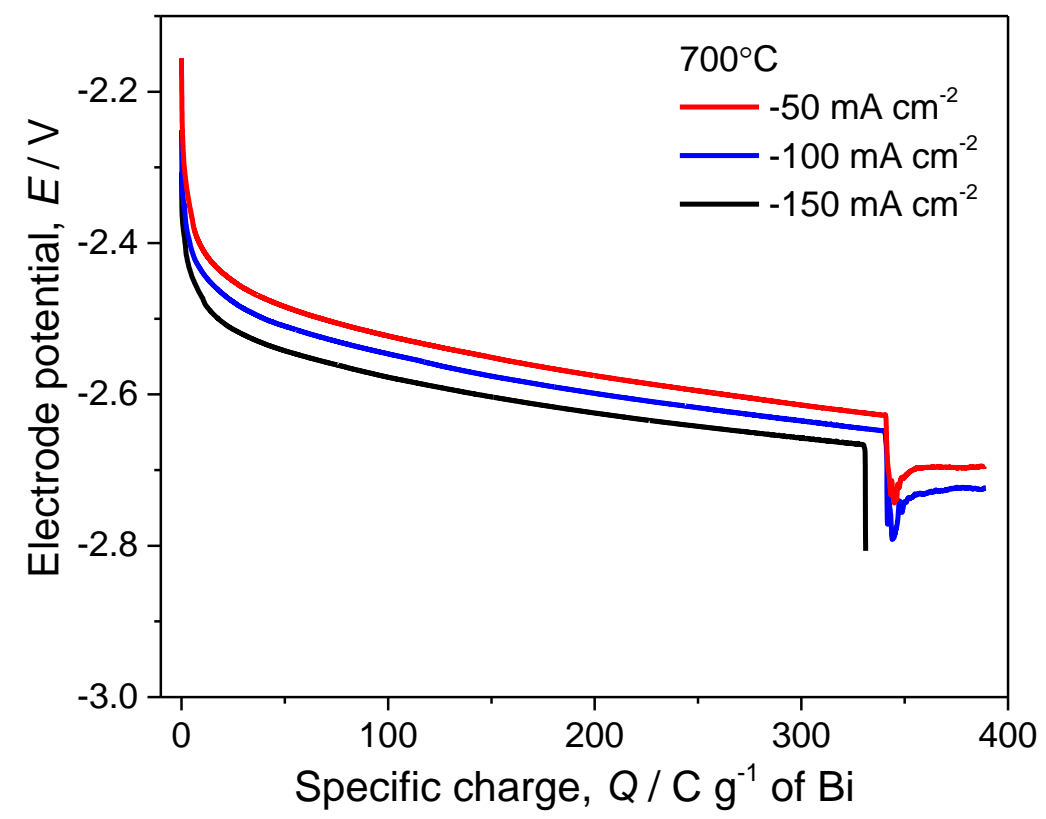

Figure 4c.

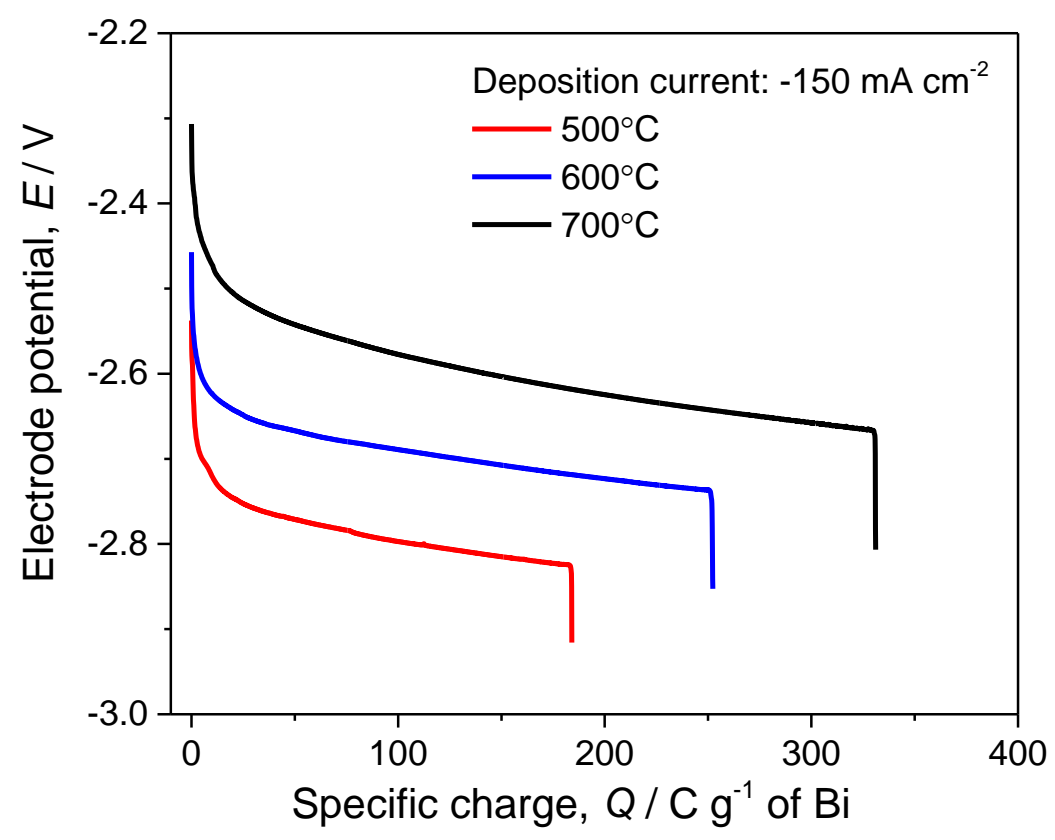

Figure 4d. 


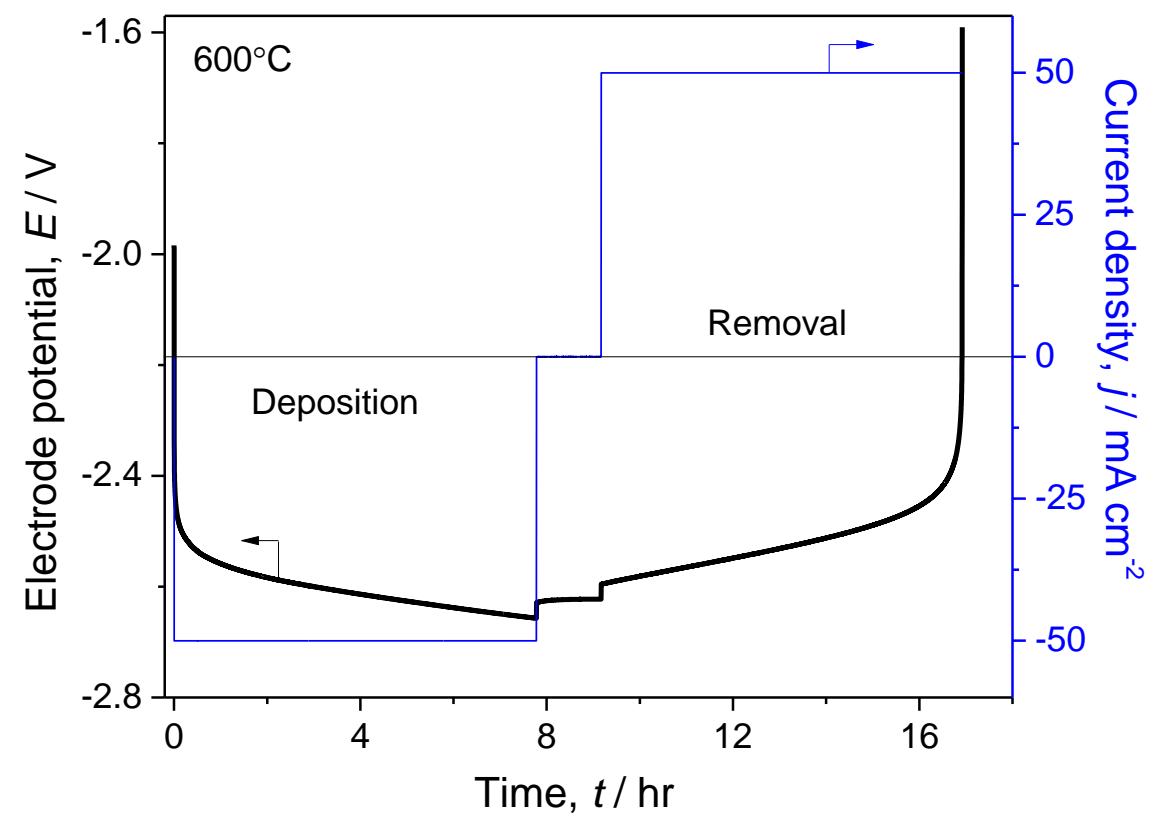

Figure 5. 


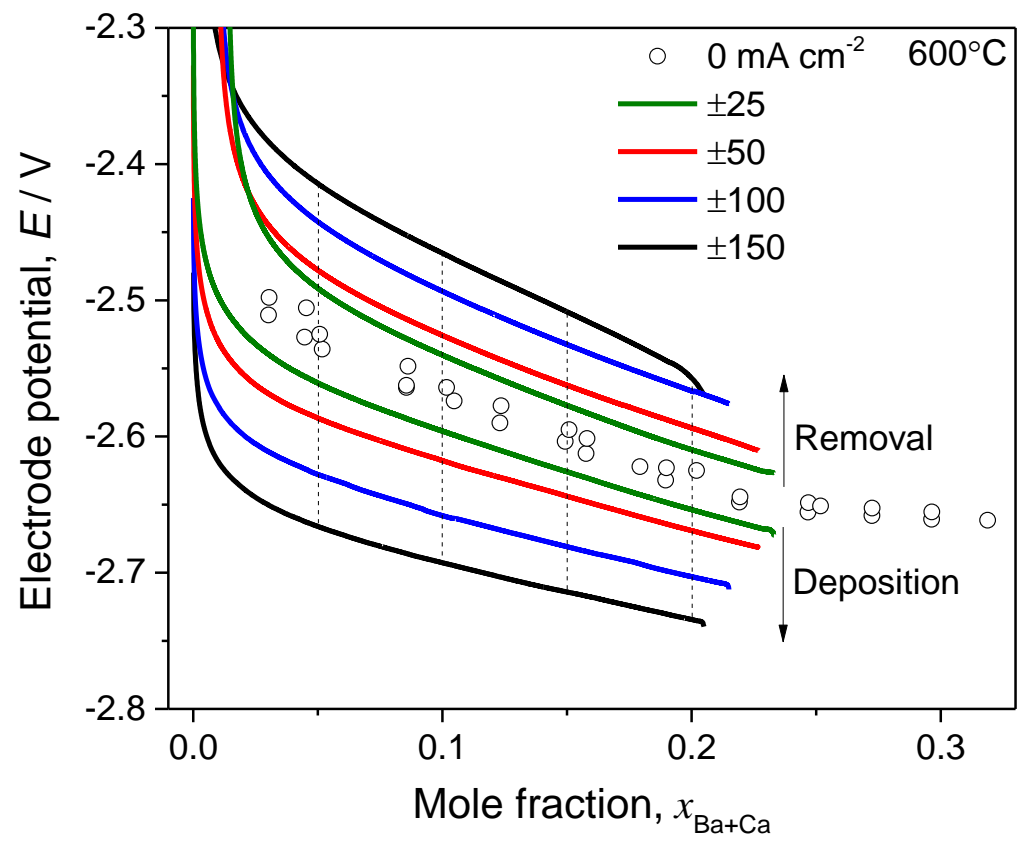

Figure 6a.

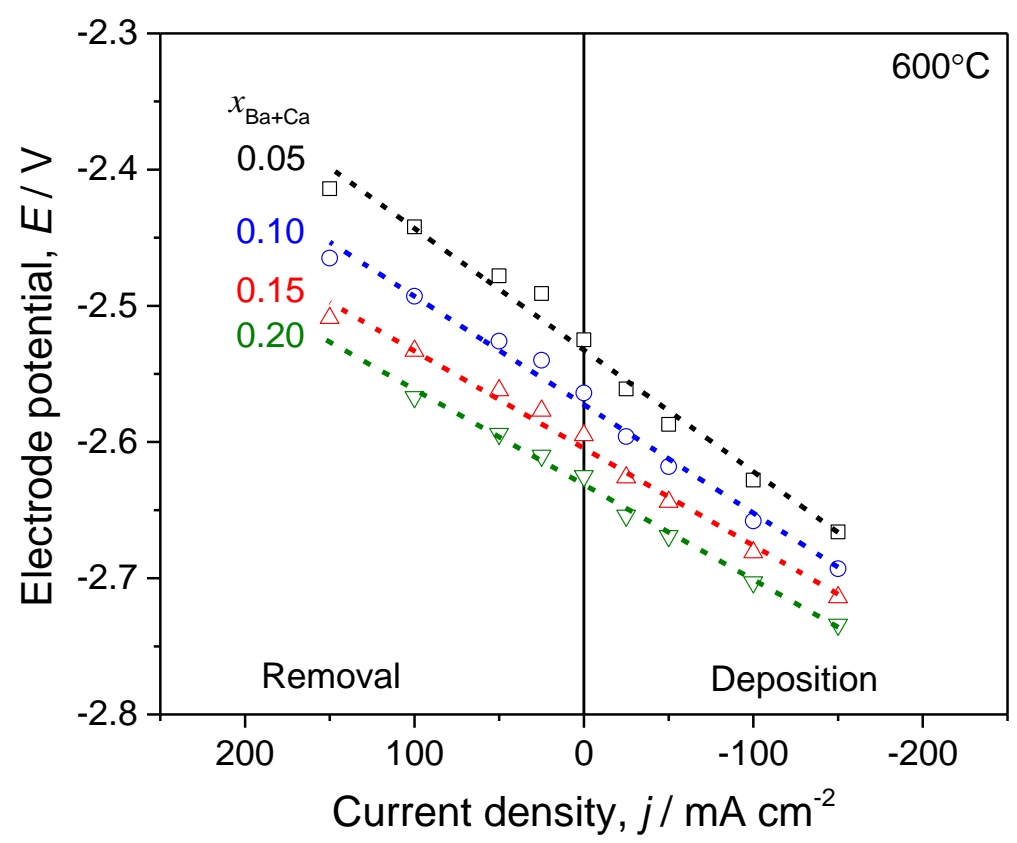

Figure 6b. 


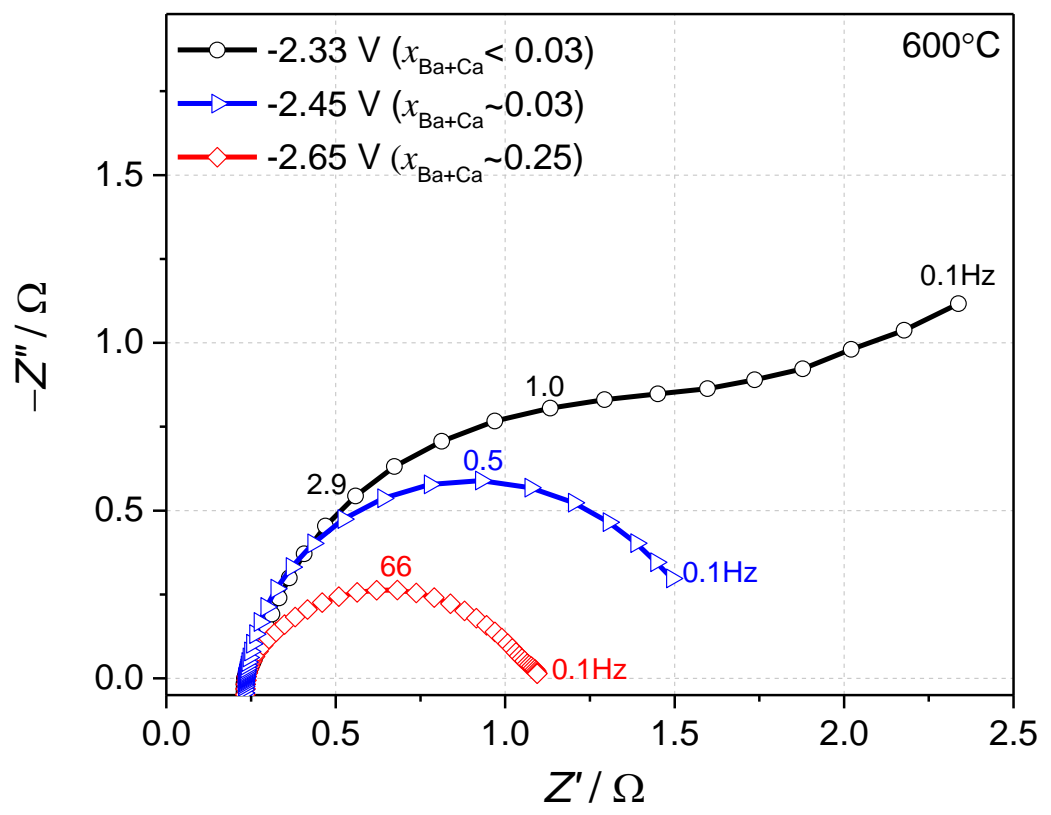

Figure 7a.

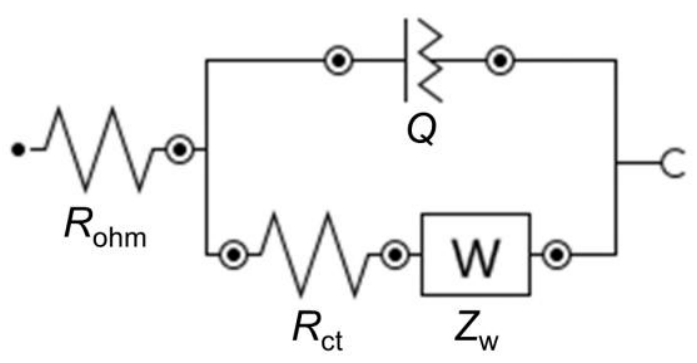

Inset in Figure 7a 


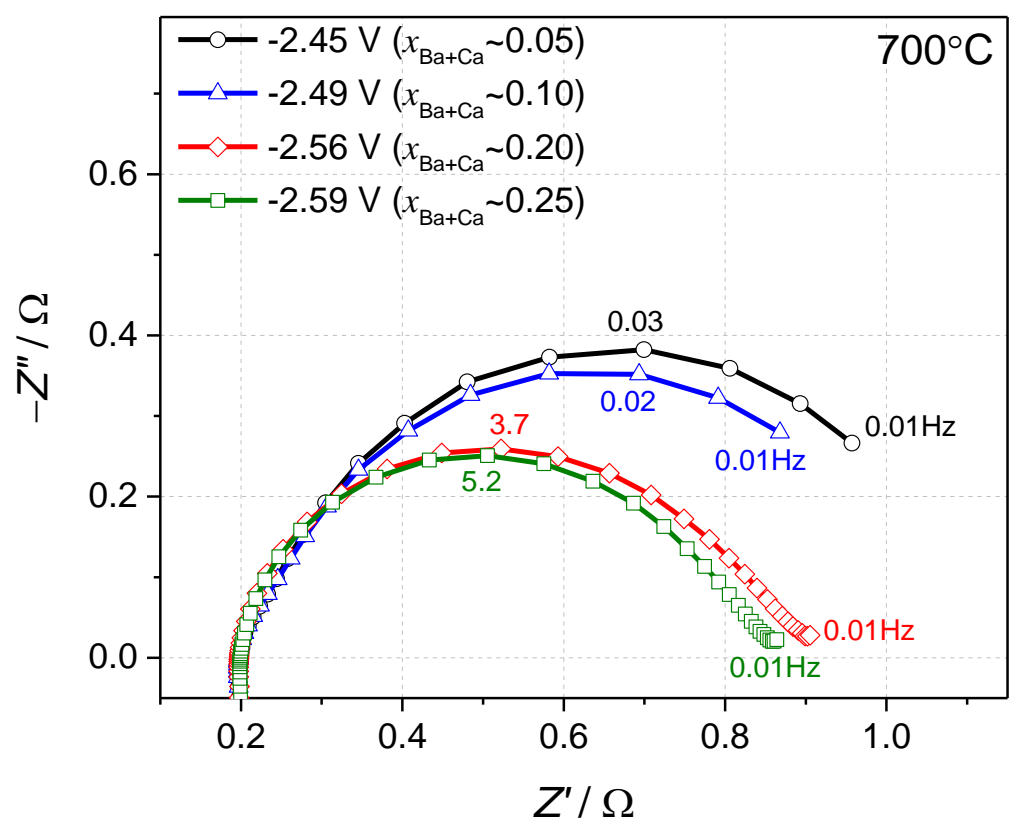

Figure 7b.

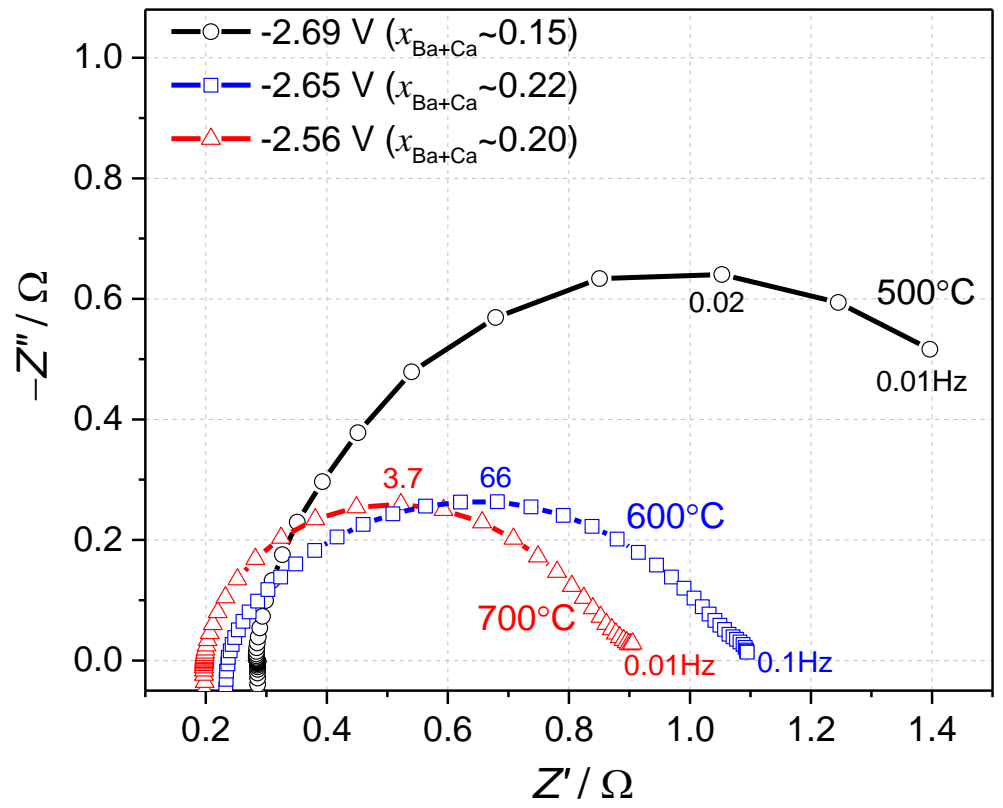

Figure 7c. 